\title{
Daily dietary intake of chromium in southern Spain measured with duplicate diet sampling
}

\author{
Elena Garcia ${ }^{1}$, Carmen Cabrera ${ }^{1 *}$, M. Luisa Lorenzo ${ }^{1}$, Joaquin Sánchez ${ }^{2}$ and M. Carmen López ${ }^{1}$ \\ ${ }^{1}$ Department of Nutrition and Bromatology, School of Pharmacy, University of Granada, E-18012 Granada, Spain \\ ${ }^{2}$ Department of Statistics and Applied Mathematics, Miguel Hernández University, E-03202 Elche (Alicante), Spain
}

(Received 24 July 2000 - Revised 11 December 2000 - Accepted 24 February 2001)

\begin{abstract}
We measured daily dietary $\mathrm{Cr}$ intake in southern Spain by sampling duplicate diets for seven consecutive days in different population groups. $\mathrm{Cr}$ was determined by electrothermal atomization-atomic absorption spectrometry. The samples were mineralized in a digestion block with $\mathrm{HNO}_{3}, \mathrm{HClO}_{4}$ and $\mathrm{V}_{2} \mathrm{O}_{5}$. A total of 161 duplicate diets from twenty-three subjects were analysed, and mean levels of $\mathrm{Cr}$ intake ranged from 9.39 to $205.16 \mu \mathrm{g} / \mathrm{d}$. Mean $\mathrm{Cr}$ intake $(100 \mu \mathrm{g} / \mathrm{d})$ was similar to levels found for most other countries, and was within the range recommended by the National Research Council for a safe and adequate daily intake $(50-200 \mu \mathrm{g} / \mathrm{d})$. Chromium intake correlated significantly with energy, protein and carbohydrate intake, and with the daily intake of $\mathrm{Zn}, \mathrm{Fe}, \mathrm{Mg}, \mathrm{K}, \mathrm{Na}, \mathrm{Ca}$ and nicotinic acid in the diets analysed.
\end{abstract}

Dietary chromium: Duplicate diet: Nutrient intake: Correlation

$\mathrm{Cr}$, an essential element in human nutrition, is involved in carbohydrate and lipid metabolism (Prasad, 1985). The most frequent manifestation of chromium deficiency is altered glucose tolerance (Mertz, 1995). This nutrient has also been associated with diabetes and cardiovascular disease. Some authors have reported beneficial effects of dietary supplementation with chromium, particularly in groups in which deficiencies are frequent (Van Cauwenbergh et al. 1996). The National Research Council (1989) considered a varied, balanced diet the best way to guarantee adequate $\mathrm{Cr}$ intake; the recommended dietary intake for adults was set at 50-200 $\mu \mathrm{g} / \mathrm{d}$. However, at least one study noted the lack of reliable methods to evaluate chromium status in living organisms, and have called for further research in dietary Cr levels (Wood et al. 1995).

Estimating the dietary intake of $\mathrm{Cr}$ (or any other trace element) is made difficult by the various sources of error and the lack of advice as to how to avoid them (Pennington et al. 1986; Southgate et al. 1989; Nielsen, 1994). Among the methods proposed thus far, chemical analysis of duplicate diets provides the most precise and reliable data (Anderson \& Kozlovsky, 1985; Cameron \& Van Staveren, 1988; Nielsen 1994; Van Cauwenbergh et al. 1996; Biego et al. 1998, 1999).

In this study we evaluated the dietary intake of $\mathrm{Cr}$ in southern Spain by chemically analysing duplicate diets consumed by members of different population groups. To date, no data on micronutrient intake have been published for this population, and it has thus not been possible to determine whether dietary supplies can be considered adequate in this population on the basis of National Research Council recommendations (1989). In addition we looked for possible correlations between $\mathrm{Cr}$ intake and the intake of energy and macronutrients.

\section{Materials and methods Sampling strategies}

To determine the dietary intake of trace elements, study designs that include collection and preparation of foods ready for consumption (by cooking) are believed to produce the most realistic and reliable results (Anderson et al. 1993; Robberecht et al. 1994; Van Cauwenbergh et al. 1996). Therefore, duplicate meals, drinking water, beverages and between-meal snacks were collected over $24 \mathrm{~h}$ periods in different places in southern Spain:

- Acuartelamiento de Cervantes, Grupo de Operaciones Especiales Santa Fe II (Granada). The dining hall of this military base serves meals to $115-120$ persons.

- Colegio Mayor Jesús-María (Granada), a university residence providing full board to 190-200 students.

- Families consisting of two to ten members residing in the city of Granada. 
Table 1. Instrument parameters for $\mathrm{Cr}$ determination in diets by electrothermal atomization atomic absorption spectrometry

\begin{tabular}{ll}
\hline Wavelength $(\mathrm{nm})$ & $357 \cdot 9$ \\
Slit width $(\mathrm{nm})$ & $0 \cdot 7$ \\
Atomization system & Stabilized temperature \\
& platform furnace \\
Ashing temperature $\left({ }^{\circ} \mathrm{C}\right)$ & 1650 \\
Atomization temperature $\left({ }^{\circ} \mathrm{C}\right)$ & 2500 \\
Injection volume $(\mu \mathrm{l})$ & 10 \\
Matrix modifier & $50 \mu \mathrm{g} \mathrm{Mg}\left(\mathrm{NO}_{3}\right)_{2}$ \\
\hline
\end{tabular}

- Students from out of town living outside the home in the city of Granada.

A total of 161 duplicate diets from twenty-three subjects were sampled for seven consecutive days between January and July of 1997. Each participant also recorded all foods and beverages consumed on a daily diet card. To determine the dietary intake of macro- and micronutrients, food intake was transformed into energy and nutrients by a computer program based on Wander's food composition tables (Jiménez et al. 1998).

\section{Materials}

To eliminate contamination by detergents and samples, glassware and polyethylene sample containers were washed with tap water after each use, soaked in $6 \mathrm{M} \mathrm{HNO}_{3}$ (at least overnight), and rinsed several times with ultrapure water.

\section{Sample preparation}

The food was subjected to a simulated eating procedure using normal knives and forks. Different food items were sliced and inedible parts thrown away. The remaining parts were homogenized and the total amounts of food and beverages weighed. After further homogenization in a blender with Teflon-coated parts (Van Cauwenbergh et al. 1996), several aliquots of about $100 \mathrm{~g}$ were dried in a microwave oven (Moulinex FM-460, Moulinex, F-75008 Paris, France) under controlled temperature conditions (Cabrera et al. 1994a,b). About 0.4 g dried sample was put into a Pyrex tube and subjected to acid mineralization using a digestion block (Selecta). Samples were treated with $5 \mathrm{ml}$ of $65 \%$ (vol./vol.) nitric acid (Merck, D-64293 Darmstadt 1, Germany; suprapure) and a few micrograms $\mathrm{V}_{2} \mathrm{O}_{5}$ (Merck; analytical grade) as a catalyst, at $120^{\circ} \mathrm{C}$ for $90 \mathrm{~min}$. Then the mixture was cooled, $1 \mathrm{ml}$ of $70 \%$ (vol./vol.) perchloric acid was added, and the mixture was heated at $120^{\circ} \mathrm{C}$ for $90 \mathrm{~min}$. Solutions were left to cool to room temperature and diluted to a final volume of $25 \mathrm{ml}$ with ultrapure water $(18 \mathrm{M} \Omega \cdot \mathrm{cm}$ specific resistivity, MilliQ system, Millipore, F-91191 Gifsur-Yvette, France). Cr in the resulting solutions was determined by electrothermal atomization atomic absorption spectrometry. Three portions of each sample were analysed. Caution: Perchloric acid should not be allowed to evaporate to dryness and should only be used in an appropriate fume hood.

\section{Analytical procedure}

We used a Perkin-Elmer 1100B double-beam atomic absorption spectrophotometer equipped with a deuterium background corrector (Perkin-Elmer, Norwalk, CT, USA) and a hollow $\mathrm{Cr}$ cathode lamp made by the same manufacturer. A Perkin-Elmer HGA-700 furnace with pyrolytically coated graphite tubes and a L'vov platform (Perkin-Elmer) were used. The samples were injected manually with a Pipetman micropipette. Argon of $99.999 \%$ purity at $300 \mathrm{ml} / \mathrm{min}$ flow was used as the internal gas. The samples were atomised under the conditions shown in Table 1. Furnace conditions were optimized on the basis of time-temperature assays. Use of a L'vov platform improved the reproducibility of the results. Several matrix modifiers were tested, and $\mathrm{Mg}\left(\mathrm{NO}_{3}\right)_{2}$ (Merck; analytical grade) gave the best results. Argon flow was stopped during atomization to increase sensitivity; this did not alter the usable life of the tube. Analyses were done in peak area mode (integrated absorbance). Optimized assay conditions obviated most matrix interferences and other sources of unspecific absorption.

\section{Analytical characteristics}

The detection limit was calculated according to the rules of the International Union of Pure and Applied Chemistry (Long \& Winefordner, 1983). Sensitivity and selectivity of the analytical conditions were evaluated. Precision was checked with ten determinations of five samples. Precision as interday reproducibility was tested by analysing five samples in $6 \mathrm{~d}$. Accuracy was checked by recovery of known amounts of analyte added to five samples chosen at random. The results are summarized in Table 2 . We also used a certified reference material of the International

Table 2. Analytical characteristics of the proposed method to determine $\mathrm{Cr}$ in diets by electrothermal atomization atomic absorption spectrometry

\begin{tabular}{|c|c|c|c|c|c|}
\hline \multirow{2}{*}{$\begin{array}{l}\text { Detection limit }{ }^{\mathrm{a}} \\
\text { (pg) }\end{array}$} & \multirow{2}{*}{$\begin{array}{c}\text { Characteristic mass } \\
(\mathrm{pg})\end{array}$} & \multicolumn{2}{|c|}{ Recovery $^{c}(\%)$} & \multirow{2}{*}{$\begin{array}{c}\text { Precision RSD } \\
(\%)\end{array}$} & \multirow{2}{*}{$\begin{array}{l}\text { Blank-to-sample } \\
\text { slope ratio }\end{array}$} \\
\hline & & mean & SD & & \\
\hline 1.0 & 3.0 & 99.00 & $2 \cdot 8$ & $\begin{array}{l}5 \cdot 0^{d} \\
6 \cdot 6^{e}\end{array}$ & $0.985-1.080$ \\
\hline
\end{tabular}

RSD, relative standard deviation.

a Detection limit is analyte concentration corresponding to three times the SD of the blank for an injection volume of $10 \mu \mathrm{l}$.

${ }^{\mathrm{b}}$ Characteristic mass in $\mathrm{pg} / 0.0044 \mathrm{~A} \cdot \mathrm{s}$.

c Results obtained from recovery assays of five samples.

${ }^{d}$ Relative SD for ten replicate determinations in each of five samples.

e Relative SD for six replicate determinations (interday) in each of five samples. 
Table 3. Accuracy and precision of the proposed method against a standard reference material

$(\mathrm{Cr}$ values are mean and SD at a $95 \% \mathrm{Cl}$ about the mean for ten samples)

\begin{tabular}{|c|c|c|c|c|c|c|}
\hline \multirow{3}{*}{$\begin{array}{l}\text { Reference } \\
\text { material }\end{array}$} & \multicolumn{4}{|c|}{ Cr values ( $\mu \mathrm{g} / \mathrm{g}$ dry $w t)$} & \multirow{3}{*}{$\begin{array}{c}\text { Accuracy } \\
(\%)\end{array}$} & \multirow{3}{*}{$\begin{array}{l}\text { Precision } \\
\text { RSD (\%) }\end{array}$} \\
\hline & \multicolumn{2}{|c|}{ Certified } & \multicolumn{2}{|c|}{ Determined } & & \\
\hline & Mean & SD & Mean & SD & & \\
\hline $\begin{array}{l}\text { IAEA-H-9 } \\
\text { Mixed Human } \\
\text { Diet }\end{array}$ & 0.150 & 0.054 & 0.148 & 0.015 & 98.67 & $10 \cdot 13$ \\
\hline
\end{tabular}

Table 4. Cr dietary intake ( $24 \mathrm{~h}$ periods for seven consecutive days)

\begin{tabular}{|c|c|c|c|c|}
\hline \multirow[b]{2}{*}{ Subject } & \multirow[b]{2}{*}{ Sex } & \multirow[b]{2}{*}{ Age (years) } & \multicolumn{2}{|c|}{ Cr dietary intake $(\mu \mathrm{g} / \mathrm{d})$} \\
\hline & & & Mean & Range \\
\hline 1 & Woman & $50-60$ & $136 \cdot 00$ & $53.37-301.02$ \\
\hline 2 & Man & $60-70$ & 137.40 & $38.50-272.90$ \\
\hline 3 & Woman & $50-60$ & 77.56 & $18 \cdot 77-169 \cdot 80$ \\
\hline 4 & Woman & $20-30$ & 99.66 & $18 \cdot 66-190 \cdot 90$ \\
\hline 5 & Man & $20-30$ & 47.87 & $23.37-84.94$ \\
\hline 6 & Woman & $20-30$ & $60 \cdot 31$ & $29.94-115.50$ \\
\hline 7 & Man & $20-30$ & 43.73 & $17 \cdot 94-64 \cdot 25$ \\
\hline 8 & Woman & $20-30$ & 49.34 & $14 \cdot 14-84 \cdot 16$ \\
\hline 9 & Man & $20-30$ & $130 \cdot 45$ & $47 \cdot 65-416 \cdot 64$ \\
\hline 10 & Man & $20-30$ & $112 \cdot 70$ & $35.86-146.04$ \\
\hline 11 & Woman & $30-40$ & $130 \cdot 51$ & $49 \cdot 25-193.80$ \\
\hline 12 & Woman & $20-30$ & 27.41 & $3 \cdot 65-127 \cdot 60$ \\
\hline 13 & Woman & $60-70$ & $165 \cdot 78$ & $83 \cdot 87-236 \cdot 63$ \\
\hline 14 & Woman & $20-30$ & $75 \cdot 18$ & $44.97-110.40$ \\
\hline 15 & Woman & $50-60$ & 28.52 & $24.75-35.39$ \\
\hline 16 & Man & $20-30$ & $120 \cdot 70$ & $113 \cdot 20-134 \cdot 40$ \\
\hline 17 & Man & $20-30$ & $45 \cdot 11$ & $19.30-87.93$ \\
\hline 18 & Man & $20-30$ & 38.07 & $30.61-45.53$ \\
\hline 19 & Woman & $20-30$ & $205 \cdot 16$ & $157.69-252.63$ \\
\hline 20 & Woman & $20-30$ & $171 \cdot 75$ & $160 \cdot 10-175 \cdot 30$ \\
\hline 21 & Woman & $30-40$ & 83.78 & $80.65-90.00$ \\
\hline 22 & Woman & $20-30$ & $9 \cdot 39$ & $9.00-11.30$ \\
\hline 23 & Woman & $20-30$ & $83 \cdot 20$ & $80 \cdot 50-87 \cdot 85$ \\
\hline
\end{tabular}

Table 5. Dietary intake of $\mathrm{Cr}$ in different Spanish populations

\begin{tabular}{lrr}
\hline & \multicolumn{2}{c}{ Dietary intake $(\mu \mathrm{g} /$ day $)$} \\
\cline { 2 - 3 } Population groups & Mean & \multicolumn{1}{c}{ Range } \\
\hline $\begin{array}{l}\text { Families }(n \text { 6; males and females) } \\
\text { Students in university residence } \\
\quad(n 6 \text {; females) }\end{array}$ & 112.63 & $24.75-301.02$ \\
$\begin{array}{l}\text { Students living outside the home } \\
\quad(n \text { 6; males and females) }\end{array}$ & 82.88 & $3.65-252.63$ \\
\begin{tabular}{l} 
Military personnel ( $n$ 5; males) \\
\hline
\end{tabular} & 121.60 & $35.86-416.64$ \\
\hline
\end{tabular}

Atomic Energy Analytical Quality Services of Vienna (IAEA-H-9 Mixed Human Diet; Table 3).

The detection limit and sensitivity were suitable for the range of $\mathrm{Cr}$ concentrations encountered. Analytical precision and accuracy were acceptable (Horwitz et al. $1980,1990)$. In the addition method for all samples, slope ratio values were close to 1 (Table 2), indicating that the standard addition method was unnecessary and consequently simplifying the analysis greatly.

\section{Results and discussion}

The mean daily $\mathrm{Cr}$ intake $(24 \mathrm{~h}$ periods for seven consecutive days) in the diets we analysed ranged from $9 \cdot 39$ to $205 \cdot 16 \mu \mathrm{g} / \mathrm{d}$ (Table 4 ). The mean daily Cr intake in the total samples we analysed was close to $100 \mu \mathrm{g} / \mathrm{d}$, a value within the 50-200 $\mu \mathrm{g} / \mathrm{d}$ range recommended by the National Research Council. Only five diets consumed by different persons (belonging to different population groups) supplied more than $200 \mu \mathrm{g} / \mathrm{d}$.

The large variations in dietary $\mathrm{Cr}$, even within a single subject during a 1-week period, illustrate the influence of composition of the diet, which may in turn be affected by the presence in some meals of Cr-rich foods. When we compared the different meals eaten by individuals, we found that higher daily $\mathrm{Cr}$ intakes were related to meat and dairy products. We also observed a high $\mathrm{Cr}$ intake in diets that contained foods made with whole wheat (bread, biscuits, noodles, etc.) and brown sugar. We determined $\mathrm{Cr}$ presence in food and beverages, and we concluded that the presence is higher in dairy products, meat, stimulant drinks and infusions (especially tea and coffee), and cereals and related products (Cabrera et al. 1996; Lendínez et al. 1998; Garcia et al. 1999a,b). The high consumption rate of these products might explain the high values of $\mathrm{Cr}$ intake for some individuals included in this study. In addition, other products such as spices and aromatic herbs that are widely consumed in the Spanish diet and in the Mediterranean diet, in general could contribute to dietary intake of this element. We determined the $\mathrm{Cr}$ presence in seventeen different spices and aromatic herbs; $\mathrm{Cr}$ concentrations ranged from not detectable to $1.42 \mu \mathrm{g} / \mathrm{g}$ (dry wt.) and $\mathrm{Cr}$ presence was detected in $95 \%$ of samples (Garcia et al. 2000).

There were no statistically significant differences in $\mathrm{Cr}$ intake between population groups $(P=0 \cdot 05$; Table 5). Mean daily $\mathrm{Cr}$ intake for women $(93.57 \mu \mathrm{g} / \mathrm{d})$ was higher than for men $(84.54 \mu \mathrm{g} / \mathrm{d})$. The highest values were found for subjects between 30 and 60 years of age. These findings are similar to the data reported in early studies in other countries (Table 6).

Descriptive statistics for daily $\mathrm{Cr}$ intake are shown in Table 7. Approximately $55 \%$ of the daily $\mathrm{Cr}$ intakes were within the $50-200 \mu \mathrm{g} / \mathrm{d}$ range, and $90 \%$ of the daily chromium $\mathrm{Cr}$ intakes were below $200 \mu \mathrm{g} / \mathrm{d}$. Analysis of variance of the data showed statistically significant differences in mean $\mathrm{Cr}$ intakes between individuals $(P=0 \cdot 05)$. We then used the least significant difference test to identify three ranges of daily $\mathrm{Cr}$ intake: high $(>104 \mu \mathrm{g} / \mathrm{d})$, moderate $(42-104 \mu \mathrm{g} / \mathrm{d})$ and low $(<42 \mu \mathrm{g} / \mathrm{d})$. Statistical analyses were done using Statgraphic Statistical software (v. 5.0, Statgraphics, 1991).

Our findings showed that $55 \%$ of the diets consumed by our subjects provided amounts of $\mathrm{Cr}$ within the range recommended by the National Research Council (1989). In terms of mean weekly intake, none of the participants in this study consumed more than $200 \mu \mathrm{g} / \mathrm{d}$ (only one subject consumed $205 \mu \mathrm{g} / \mathrm{d}$ ), and only four subjects received significantly less than $50 \mu \mathrm{g} / \mathrm{d}$. Some recent studies noted that the lowest intake considered adequate may be higher than the actual nutritional requirements, as some set the 
Table 6. Daily dietary $\mathrm{Cr}$ intake in countries other than Spain

\begin{tabular}{|c|c|c|c|c|}
\hline $\begin{array}{l}\text { Population } \\
\text { group }\end{array}$ & Location & $\begin{array}{l}\text { Sampling } \\
\text { technique }\end{array}$ & $\begin{array}{c}\mathrm{Cr} \\
(\mu \mathrm{g} / \mathrm{d})\end{array}$ & Reference \\
\hline Adult women & Canada & Duplicate diet & 47 & Gibson et al. 1983 \\
\hline Adults & Belgium & Duplicate diet & 240 & Buchet et al. 1983 \\
\hline Males & Norway & Duplicate diet & 29 & Bibow \& Salbu, 1986 \\
\hline Adults & Spain & Shopping basket & 120 & Farré \& Lagarda, 1986 \\
\hline Families & Belgium & Duplicate portion & 29-95 & Brätter \& Schramel, 1987 \\
\hline Males and females & Sweden & Duplicate diet & 160 & Abdulla et al. 1989 \\
\hline Fifteen subjects & Sweden & Duplicate portion & 20 & Jorhem et al. 1989 \\
\hline Industry employees & Spain & Duplicate diet & $110-140$ & Barbera et al. 1989 \\
\hline Different groups & Brazil & Self-selected diets & 85 & Parr et al. 1990 \\
\hline Not stated & Sweden & Shopping basket & 22 & Becker \& Kumpulainen, 1991 \\
\hline Women (23-28 years) & Finland & Food record & 31 & Kumpulainen, 1992 \\
\hline Different groups & Spain & Food consumption & 99 & Moreiras \& Cuadrado, 1992 \\
\hline Families & Spain & Duplicate diet & 129 & Schuhmacher et al. 1993 \\
\hline Adults & USA & Duplicate diet & 233 & Anderson et al. 1993 \\
\hline Military Academy & Belgium & Duplicate portion & $89 \cdot 1-125 \cdot 2$ & Van Cauwenbergh et al. 1996 \\
\hline University hopital & Belgium & Duplicate portion & $20 \cdot 1-51 \cdot 0$ & Van Cauwenbergh et al. 1996 \\
\hline Military quarters & Belgium & Duplicate portion & $30.8-57.9$ & Van Cauwenbergh et al. 1996 \\
\hline Different groups & Italy & Household food & 146 & Van Cauwenbergh et al. 1996 \\
\hline Adults & Japan & Duplicate diet & 47 & Van Cauwenbergh et al. 1996 \\
\hline
\end{tabular}

Table 7. Summary of descriptive statistics from 161 duplicate diets, sampled for 7 consecutive days (with twenty-three subjects) using Pearson's correlation test

\begin{tabular}{|c|c|c|c|c|c|c|c|}
\hline & \multirow[b]{2}{*}{ Mean } & \multirow[b]{2}{*}{ SD } & \multirow[b]{2}{*}{ Minimum } & \multirow[b]{2}{*}{ Maximum } & \multicolumn{3}{|c|}{ Percentiles } \\
\hline & & & & & 25 & 50 & 75 \\
\hline $\begin{array}{l}\text { Cr intake } \\
\text { In Cr intake }\end{array}$ & $\begin{array}{r}91.83 \\
4.22\end{array}$ & $\begin{array}{r}69.76 \\
0.83\end{array}$ & $\begin{array}{l}9 \cdot 39 \\
2 \cdot 24\end{array}$ & $\begin{array}{r}416.64 \\
6.03\end{array}$ & $\begin{array}{r}36.06 \\
3.59\end{array}$ & $\begin{array}{r}77.60 \\
4.35\end{array}$ & $\begin{array}{r}129.64 \\
4.86\end{array}$ \\
\hline
\end{tabular}

minimum daily amount at closer to $25 \mu \mathrm{g} / \mathrm{d}$ than $50 \mu \mathrm{g} / \mathrm{d}$ (Nielsen, 1994; Wood et al. 1995). In the United Kingdom the recommended daily intake is $25 \mu \mathrm{g}$ for adults and $0 \cdot 1-$ $1.0 \mu \mathrm{g}$ for children (Committee on Medical Aspects of Food Policy, 1991). However, Wood et al. (1995) consider the available data on $\mathrm{Cr}$ contents in different foods to be scarce and inadequate, and suggest that reanalysis is needed.

Farré \& Lagarda (1986) noted that the possible causes of $\mathrm{Cr}$ deficiency include intestinal infection, metabolic disorders, and inadequate intake of the trace element because of low $\mathrm{Cr}$ content in the diet or the consumption of many highly processed foods. As noted by Mertz (1982),

Table 8. Correlation between the intake of $\mathrm{Cr}$ and other nutrients from the diets analysed

\begin{tabular}{lcc}
\hline & $\begin{array}{c}\text { Pearson correlation } \\
\text { coefficient }\end{array}$ & $\begin{array}{c}\text { Significance } \\
\text { level }\end{array}$ \\
\hline Carbohydrate & 0.219 & $P<0.05$ \\
Fat & -0.107 & - \\
Protein & -0.219 & $P<0.05$ \\
Zn & 0.353 & $P<0.01$ \\
$\mathrm{Fe}$ & 0.279 & $P<0.01$ \\
$\mathrm{Mg}$ & 0.355 & $P<0.01$ \\
$\mathrm{~K}$ & 0.308 & $P<0.01$ \\
$\mathrm{Na}$ & 0.278 & $P<0.01$ \\
$\mathrm{Ca}$ & 0.356 & $P<0.01$ \\
Ascorbic acid & 0.034 & - \\
Folic acid & 0.178 & - \\
Nicotinic acid & 0.277 & $P<0.01$ \\
\hline
\end{tabular}

the well-known effect of $\mathrm{Cr}$ on three risk factors for coronary ischaemia (i.e. circulating insulin, glucose tolerance and serum lipoproteins) should stimulate further in-depth research on the influence of dietary $\mathrm{Cr}$ intake in humans.

Several authors have noted that the intake of a given element can be directly or inversely related with the intake of other nutrients, particularly minerals and vitamins (Concon, 1988; Committee on Medical Aspects of Food Policy, 1991; Mertz, 1995). We looked for statistically significant relationships (Pearson correlation) between $\mathrm{Cr}$ intake and the intake of energy and macronutrients (Table 8). The results revealed that $\mathrm{Cr}$ intake was significantly related with energy, protein and carbohydrate intake, and with $\mathrm{Zn}, \mathrm{Fe}, \mathrm{Mg}, \mathrm{K}, \mathrm{Na}, \mathrm{Ca}$ and nicotinic acid intake $(P<0 \cdot 01)$.

\section{Conclusion}

The amounts of $\mathrm{Cr}$ in the normal diet consumed by our subjects in southern Spain varied widely. The variations were influenced by the types of foods and beverages consumed (typical of the Mediterranean diet). A varied, balanced diet supplies adequate amounts of $\mathrm{Cr}$; however, because of the wide range of intakes and the limited capacity of the human body to absorb this element, further research will be needed to reliably establish recommended dietary intakes of $\mathrm{Cr}$. 


\section{Acknowledgements}

We thank Karen Shashok for translating parts of the manuscript into English.

\section{References}

Abdulla M, Behbehani A \& Dashti H (1989) Dietary intake and bioavailability of trace elements. Biological Trace Element Research 21, 173-178.

Anderson RA, Bryden NA \& Polansky MM (1993) Dietary intake of calcium, chromium, copper, iron, magnesium, manganese and zinc: duplicate plate values corrected using derived nutrient intake. Journal of the American Dietetic Association 93, 462-464.

Anderson RA \& Kozlovsky AS (1985) Chromium intake, absorption and excretion of subjects consuming self-selected diets. American Journal of Clinical Nutrition 41, 1177-1183.

Barbera R, Farré R \& Lozano A (1989) Oral intake of cadmium, lead, cobalt, chromium, nickel, copper, manganese and zinc in the Spanish diet, estimated by a duplicate meal study. Journal of Micronutrient Analysis 6, 47-57.

Becker W \& Kumpulainen J (1991) Contents of essential and toxic mineral elements in Swedish market-basket diets in 1987. British Journal of Nutrition 66, 151-153.

Bibow K \& Salbu B (1986) Trace elements in Norwegian diets. Acta Pharmacological Toxicology 59, 9-30.

Biego GH, Joyeux M, Hartemann P \& Debry G (1998) Daily intake of essential minerals and metallic micropollutants from foods in France. The Science of the Total Environment 217, 27-36.

Biego GH, Joyeux M, Hartemann P \& Debry G (1999) Determination of dietary tin intake in an adult French citizen. Archives of Environmental Contamination Toxicology 36, 227-232.

Brätter P \& Schramel P (1987) Trace Element Analytical Chemistry in Medicine and Biology. Berlin: De Gruyter.

Buchet JP, Lauwerys R, Vandervoorde A \& Pycke JM (1983) Oral daily intake of $\mathrm{Cd}, \mathrm{Pb}, \mathrm{Mn}, \mathrm{Cu}, \mathrm{Cr}, \mathrm{Hg}, \mathrm{Co}, \mathrm{Zn}$ and $\mathrm{As}$ in Belgium: a duplicate meal study. Food Chemistry and Toxicology 21, 19-24.

Cabrera C, Gallego C, Lopez MC, Lorenzo ML \& Lillo E (1994b) Determination of levels of lead contamination in food and feed crops. Journal of AOAC International 77, 1249-1252.

Cabrera C, Lorenzo ML, De Mena C \& Lopez MC (1996) Chromium, copper, iron, manganese, selenium and zinc levels in dairy products: in vitro study of absorbable fractions. International Journal of Food Sciences and Nutrition 47, 331-339.

Cabrera C, Lorenzo ML, Gallego C, Lopez MC \& Lillo E (1994a) Cadmium contamination levels in seafood determined by electrothermal atomic absorption spectrometry after microwave dissolution. Journal of Agricultural and Food Chemistry 42, 126-128.

Cameron ME \& Van Staveren WA (1988) Manual on Methodology for Food Consumption Studies. Oxford: Oxford University Press.

Committee on Medical Aspects of Food Policy (1991) Dietary reference values for food energy and nutrients for the United Kingdom: Report of the panel on dietary reference. London: Her Majesty's Stationery Office.

Concon JM (1988) Food Toxicology. New York: Dekker.

Farré R \& Lagarda MJ (1986) Chromium content of foods and diets in the Spanish population. Journal of Micronutrient Analysis 2, 297-304.

Garcia E, Cabrera C, Lorenzo ML \& Lopez MC (2000) Chromium levels in spices and aromatic herbs. The Science of the Total Environment 247, 51-56.

Garcia E, Cabrera C, Sanchez J, Lorenzo ML \& Lopez MC (1999b) Chromium levels in potable water, fruit juices and soft drinks: influence on dietary intake. The Science of the Total Environment 241, 143-150.

Garcia E, Lorenzo ML, Cabrera C, Lopez MC \& Sánchez J (1999a) Trace element determination in different milk slurries. Journal of Dairy Research 66, 569-578.

Gibson RS, Anderson BM \& Sabry JH (1983) The trace metal status of a group of postmenopausal vegetarians. Journal of the American Dietetic Association 82, 246-250.

Horwitz W, Albert R, Deutsch MJ \& Thompson JN (1990) Precision parameters of methods of analysis required for nutrition labeling. Journal of the Association of Official Analytical Chemists 73, 661-680.

Horwitz W, Kamps LR \& Boyera FW (1980) Quality assurance in the analysis of foods and trace constituents. Journal of the Association of Official Analytical Chemists 63, 1344-1354.

Jiménez A, Cervera P \& Bacardí M (1998) Tablas de Composición de Alimentos. Madrid: Novartis Nutrition.

Jorhem L, Sundström B, Astrand C \& Haegglund G (1989) The levels of zinc, copper, selenium, chromium, nickel, cobalt and aluminium in the meat, liver and kidney of cattle. Zeitschrift für Lebensmittel-Untersuchung und Forschung 188, 39-44.

Kumpulainen JT (1992) Chromium content of foods and diets. Biological Trace Element Research 32, 9-18.

Lendinez E, Lopez MC, Cabrera C \& Lorenzo ML (1998) Determination of chromium in wine and other alcoholic beverages consumed in Spain by electrothermal atomic absorption spectrometry. Journal of AOAC International 8, 1043-1047.

Long GL \& Winefordner JD (1983) Limit of detection: a closer look at the IUPAC definition. Analytical Chemistry 55, 713.

Mertz W (1982) Clinical and public health significance of chromium. In Clinical, Biochemical and Nutritional Aspects of Trace Elements, pp. 10-40 [AS Prasad, editor]. New York: Alan R. Liss.

Mertz W (1995) Risk assessment of essential trace elements: new approaches to setting recommended dietary allowances and safety limits. Nutrition Research 53, 179-185.

Moreiras O \& Cuadrado C (1992) Theoretical study of the intake of trace elements (nutrients and contaminants) via total diet in certain geographical areas of Spain. Biological Trace Element Research 32, 93-103.

National Research Council (1989) Recommended Dietary Allowances. Washington, DC: National Academy of Sciences

Nielsen FH (1994) Chromium. In Modern Nutrition in Health and Disease, pp. 1030-1080 [ME Shils, JA Olson and M Shike, editors]. Malvern: Lea \& Febiger.

Parr R, Abdulla A, Aras N, Byrne A et al. (1990) In Proceedings of the TEMA-7 Symposium. Dubrovnik, May 20-25.

Pennington JA, Young BE, Wilson DB, Johnson RD \& Vanderveen JE (1986) Mineral content of foods and total diets: the selected minerals in foods survey, 1982 to 1984. Journal of the American Dietetic Association 86, 876-891.

Prasad AS (1985) Diagnostic approaches to trace element deficiencies. In Trace Elements in Nutrition of Children, pp. 20-55 [RK Chandra, editor]. New York: Nestlé Nutrition.

Robberecht HJ, Hendrix P, Van Cauwenbergh R \& Deelstra HA (1994) Actual dietary intake of selenium in Belgium, using duplicate portion sampling. Zeitschrift für LebensmittelUntersuchung und Forschung 199, 251-254.

Schuhmacher M, Domingo JL, Llobet JM \& Corbella J (1993) Dietary intake of copper, chromium and zinc in Tarragona 
province, Spain. The Science of the Total Environment 132, $3-10$.

Southgate D, Johnson Y \& Fenwick GR (1989) Nutrient Availability: Chemical and Biological Aspects. London: Royal Society of Chemistry.

Statgraphics (1991) Reference manual, version 5. Rockville, MD: STSC.
Van Cauwenbergh R, Hendrix P, Robberecht H \& Deelstra HA (1996) Daily dietary chromium intake in Belgium, using duplicate portion sampling. Zeitschrift für LebensmittelUntersuchung und Forschung 203, 203-206.

Wood RJ, Sotter PM \& Russell RM (1995) Mineral requirements of elderly people. American Journal of Clinical Nutrition 62 , 493-505. 